\title{
Economic Globalization and Gender Equality: A Case Study of India
}

\author{
Atrayee Ghosh Roy, Ph.D. \\ Department of Economics, 150 Morris Hall, Minnesota State University, Mankato, MN 56001 \\ Email: atrayee.ghosh-roy@mnsu.edu
}

\begin{abstract}
The purpose of this paper is to explore the relationship between economic globalization and gender equality in India. Using time-series data covering the span of 1990 - 2009, this study particularly examines whether the 1991 Indian trade reforms have also contributed to greater gender equality in the labor market. A simultaneous equation model is developed to estimate the effect of trade liberalization on gender inequality. The results show that trade liberalization has a positive and significant effect on gender equality in the labor market. Furthermore, the results also indicate that economic growth contributes to greater gender equality while female enrollment in higher education has a negative effect on gender equality in the labor market.
\end{abstract}

Keywords: Gender equality, economic globalization, stationary, simultaneity

JEL Classifications: F60 - Economic Impacts of Globalization: General, F69 - Economic Impacts of Globalization: Other

\section{Introduction}

Over the past three decades the world has observed an immense economic revolution promoted by rising international trade in goods and services, investment, flows of technology and information. World is more integrated than ever through trade, foreign direct investment, short-term capital flows, international flows of workers and technology. In this integrated world the economic environment has changed for all players - individuals, households and firms. The World Development Report 2012 states that "Trade openness and the spread of information and communication technologies (ICT) have increased Women's access to economic opportunities and in some cases increased their wages relative to men's."

Although there is a large literature examining the effects of international trade and investment on economic growth and labor market outcomes, globalization's impact on gender equality is an underexplored question in the economic literature. The cost of gender inequality is likely to be larger for open economies as in an integrated world competition increases and as a result discrimination reduces a country's ability to compete. Note that Becker (1971) predicts in his seminal book that an increase in competition is likely to reduce discrimination as competition raises the opportunity cost of discrimination. Also, there is a growing body of evidence in favor of a positive relationship between gender equality and economic growth. Thus, the gender aspect of globalization is a question that deserves careful attention. Using Indian data this paper attempts to fill this void in the literature by exploring the relationship between globalization and gender equality.

It is to be noted that India presents a unique case to investigate the impact of trade liberalization on gender equality in the labor market mainly for two reasons. First, prior to 1990, India was one of the most protectionist countries because of its adoption of import substitution policies. After 1990, in India the magnitude of trade liberalization was huge and more drastic than in Latin American countries like Colombia, Mexico and Brazil in their trade liberalization episodes. Second, trade reforms were not only drastic, they were also exogenous.

According to the International Monetary Fund (1998) India was "one of the most complicated and protectionist regime in the world." As a result, the Indian economy was stuck in a vicious cycle of low productivity and sluggish growth. In 1991 faced with a severe balance of payment crisis India approached the International Monetary Fund for support. The IMF assistance was conditional on structural reforms including trade liberalization and a range of economic policy reforms in the industrial, 
financial and public sectors. Since the target tariff rates were exogenously predetermined, policymakers did not have much opportunity to cater to special interest groups. Thus, India's trade liberalization episodes provide an excellent testing environment to study the effect of trade liberalization on gender inequality in the labor market.

Since the adoption of market-oriented economic reforms and trade liberalization policies in 1991, the performance of Indian economy has been quite impressive. Using time series data covering the span of 1990 -2009, this paper particularly examines whether the 1991 Indian trade reforms have also reduced the gender labor force participation gap. In order to address the potential simultaneity between dependent and independent variables this paper uses a simultaneous equation model. To the best of my knowledge no one has used simultaneous equation model approach to estimate the effect of economic globalization on gender inequality in the labor market.

\section{Reviewing Previous Studies}

As noted earlier, there are not many previous studies that explore the relationship between trade liberalization and gender inequality. Juhn, Ujhelyi and Villegas-Sanchez (2013) examine the effect of trade liberalization under NAFTA on wage inequality using establishment-level data from Mexico. Their results indicate that tariff reductions associated with the NAFTA increased both employment and wage bill shares of female workers in blue-collar jobs. They did not find any evidence of improvement of employment or wage bill shares of female workers in white collar jobs. Black and Brainerd (2004) discover that in the United States less competitive domestic industries experience a decline in residual wage gaps when they are exposed to greater competition from trade. Several other studies - Hazarika and Otero (2004), Behrman and King (2002), and Oostendorp (2004), among others - find that an increase in the magnitude of trade liberalization leads to lower gender earnings differentials. Using a sample of 92 industrialized and developing countries Busse and Spielmann (2006) find that gender equality in labor market participation rates increases with an increase in the comparative advantage in the trade of labor-intensive goods.

However, Berik, Rodgers and Zveglich (2004) find evidence that an increase in the magnitude of trade liberalization is associated with an increase in residual wage gaps between men and women in two East Asian economies or increased wage discrimination. Rodgers and Menon (2008) show that an increase in trade openness leads to larger wage gaps between men and women employed in India's less competitive manufacturing industries.

In sum, previous studies have produced mixed results. Note that to the best of my knowledge no previous studies have used simultaneous equation models to explore the relationship between trade liberalization and gender inequality. Consequently, their models may generate biased and inconsistent coefficient estimates.

\section{Country Context}

The International labour Organization (ILO) economist Steven Kapsos stated that "Despite very rapid economic growth in India in recent years, we're observing declining female labor force participation rates across all age groups, across all education levels, and in both urban and rural areas," Figure 1 and Figure 2 show that over the period of this study, 1990 - 2009, female labor force participation rate for ages 15-24 as well as the ratio of female to male labor force participation rate have been falling except for the period 2000 - 2004. Figure 3, Figure 4 and Figure 6 show that the weighted average tariff rate for all products has been falling while real GDP and the percentage of girls' enrollment in higher education have been rising over the period 1990 - 2009.

In India women's participation in the labor market is not likely to be influenced by economic and structural factors only. In a traditional society like India social norms and cultural factors play an important role in governing gender roles and responsibilities that influence women's decision to participate in the labor market. In India since men are expected to be the primary breadwinners in the family, women's absence in the labor market may be influenced by both their and households' preferences. For example, a working woman may indicate economic hardship issues for the family. Therefore, as household income increases, women will prefer not to participate in the labor market. 
Olsen and Mehta (2006) find that women who are concentrated at the bottom and top of the education distribution are more likely to work than women in the middle of the education distribution. The authors argue that poor women cannot afford to hire domestic help and so it is difficult for them to manage both domestic work and work outside the home. Therefore, poor women are more inclined to leave the labor force as household income increases. Highly educated women on the other hand can afford to hire domestic help making it easier for them to participate in the labor market. It is important to note that as wages of highly educated women increase, social norms become less restrictive because of a complex interaction between economic and cultural factors. Consequently, highly educated women are more likely to engage in outside economic activity.

\section{The Model}

The following equation is specified to test the relationship between the gender labor force participation gap and economic globalization.

$$
\frac{F_{L}}{M_{L}}=a_{o}+a_{1} G r(Y)+a_{2} R_{\text {Tariff }}+a_{3} R_{\text {Fertility }}+a_{4} \frac{G E N R_{\text {Hed }}}{T E N R_{\text {Hed }}}+a_{5} \frac{G_{e d}}{Y}
$$

where, $\frac{F_{L}}{M_{L}}$ is the ratio of female to male labor force participation rate that measures the gender labor force participation gap. The variables $G r(Y), R_{\text {Tariff }}, \mathrm{R}_{\text {fertility }}, \frac{G E N R_{H e d}}{T E N R_{H e d}}$, and $\frac{G_{E D}}{Y}$ are the growth rate of real gross domestic product, the weighted average tariff rate for all products, the fertility rate, the percentage of girls' enrollment in higher education and the share of government expenditure on education in GDP, respectively. Equation (1) is inspired by Juhn, Ujhelyi and Villegas-Sanchez (2013) and Lahoti and Swaminathan (2013).

\subsection{Dealing with the Simultaneity Bias}

The relationship between the gender labor force participation gap and economic growth is complex. There might exist a likely bi-directional relationship between the ratio of female to male labor force participation rate, $\frac{F_{L}}{M_{L}}$ and economic growth, $\operatorname{Gr}(\mathrm{Y})$, since a number of previous studies find that gender equality in the labor market stimulates economic growth. Also, there might be a potential reverse effect running from the percentage of girls' enrollment in higher education, $\frac{G E N R_{H e d}}{T E N R_{H e d}}$ to the ratio of female to male labor force participation rate. Lahoti and Swaminathan (2013) found a negative and significant effect of women's increased access to education on female labor force participation. The authors have checked the robustness of the impact of women's education and found that the impact is indeed robust. The regression equation (1) is likely to generate biased and inconsistent coefficient estimates because of the existence of potential simultaneity between $\frac{F_{L}}{M_{L}}$ and $\operatorname{Gr}(\mathrm{Y})$, and between $\frac{F_{L}}{M_{L}}$ and $\frac{G E N R_{H e d}}{T E N R_{H e d}}$. Ordinary least squares coefficient estimates will be biased and inconsistent in the presence of bi-directional relationships between dependent and independent variables.

The problem of simultaneity, of course, is best addressed using a simultaneous equation model (SEM). Therefore, a SEM that explicitly specifies the hypothesized simultaneous relationships is developed in this paper. Equation (1) thus becomes the first equation in the SEM, and other equations are introduced to estimate other relationships between variables that are part of the simultaneous relationships.

In order to capture the reverse effect of the ratio of female to male labor force participation rate on economic growth, the second equation of the SEM, which explains the growth rate of GDP, is specified. 


$$
G r(Y)=b_{o}+b_{1} G r(K)+b_{2} G r(L)+b_{3} \frac{F_{L}}{M_{L}}
$$

where $\operatorname{Gr}(\mathrm{K})$ and $\mathrm{Gr}(\mathrm{L})$ are the growth rates of capital and labor, respectively. Equation (2) indeed looks like the well-known sources of growth equation derived in a conventional manner from the neoclassical production function, which takes on the familiar Cobb-Douglas form.

$$
Y=A K^{\alpha} L^{1-\alpha}
$$

where $Y, K$ and $L$ are real GDP, capital stock and labor, respectively. $A$ is a parameter which measures the total factor productivity and it is assumed to be greater than zero.

Taking the natural logarithm of equation (3) and differentiating with respect to time yields,

$$
\dot{Y}=\dot{A}+\alpha \dot{K}+(1-\alpha) \dot{L}
$$

where $\dot{Y}, \dot{A}, \dot{K}$ and $\dot{L}$ are the growth rates of real GDP, total factor productivity, capital, and labor, respectively. $\alpha$ and 1- $\alpha$ are the relative shares of capital and labor. Equation (2) is effectively equation (4) augmented by including the ratio of female to male labor force participation rate.

A large number of studies - Edwards (1998), and Baldwin (2004), among others - widely support the hypothesis, that all other things equal, trade liberalization enhances a country's economic growth. In order to minimize the omitted variable bias, the weighted average tariff rate, $R_{\text {Tariff }}$, that measures the magnitude of trade liberalization is included in equation (2). Since government expenditure on education is likely to stimulate economic growth, the share of government expenditure on education in GDP, $\frac{G_{E D}}{Y}$, is included in equation (2). Note that Hansson and Henrekson (1994) find that education expenditure has a positive impact on the rate of growth of total factor productivity. Adding $R_{\text {Tariff }}$ and $\frac{G_{E D}}{Y}$ to equation (2) yields:

$$
G r(Y)=b_{o}+b_{1} G r(K)+b_{2} G r(L)+b_{3} \frac{F_{L}}{M_{L}}+b_{4} R_{\text {Tariff }}+b_{5} \frac{G_{e d}}{Y}
$$

In order to address the problem of simultaneity between $\frac{F_{L}}{M_{L}}$ and $\frac{G E N R_{H e d}}{T E N R_{H e d}}$, the third equation of the SEM is specified following Lahoti and Swaminathan (2013).

$$
\frac{G E N R_{\text {Hed }}}{T E N R_{\text {Hed }}}=c_{o}+c_{1} \frac{F_{L}}{M_{L}}+c_{2} R_{\text {Tariff }}+c_{3} G r(Y)+c_{4} \frac{G_{e d}}{Y}
$$

In summary, in this paper the following SEM that explicitly specifies several hypothesized simultaneous relationships is developed to estimate the relationship between trade liberalization and the gender labor force participation gap.

$$
\begin{aligned}
& \frac{F_{L}}{M_{L}}=a_{o}+a_{1} G r(Y)+a_{2} R_{\text {Tariff }}+a_{3} R_{\text {Fertility }}+a_{4} \frac{G E N R_{\text {Hed }}}{T E N R_{\text {Hed }}}+a_{5} \frac{G_{e d}}{Y}+t+\varepsilon_{1} \\
& \operatorname{Gr}(\mathrm{Y})=\mathrm{b}_{\mathrm{o}}+\mathrm{b}_{1} \operatorname{Gr}(\mathrm{K})+\mathrm{b}_{2} \operatorname{Gr}(\mathrm{L})+\mathrm{b}_{3} \frac{\mathrm{F}_{\mathrm{L}}}{\mathrm{M}_{\mathrm{L}}}+\mathrm{b}_{4} \mathrm{R}_{\text {Tariff }}+\mathrm{b}_{5} \frac{\mathrm{G}_{\text {ed }}}{\mathrm{Y}}+\mathrm{t}+\varepsilon_{2} \\
& \frac{G E N R_{\text {Hed }}}{T E N R_{\text {Hed }}}=\mathrm{c}_{\mathrm{o}}+\mathrm{c}_{1} \frac{F_{L}}{M_{L}}+c_{2} R_{\text {Tariff }}+c_{3} G r(Y)+c_{4} \frac{G_{e d}}{Y}+t+\varepsilon_{3},
\end{aligned}
$$

where $\varepsilon_{1}, \varepsilon_{2}, \varepsilon_{3}$, are stochastic error terms with mean zero and finite variance.

\section{Data}

Model (7) has been estimated using annual data for the time span of 1990 - 2009. The Appendix provides a detailed description of variables and data sources. Some of the time-series variables in model (7) may be non-stationary. Regressions involving independent nonstationary variables tend to generate "spurious" results, that is, conventional time-series tests are biased toward finding a significant 
relationship among variables in levels when in fact none exists ${ }^{1}$. The standard method for detecting nonstationary behavior in a time-series is to test for the presence of a unit root. Testing can be extended to incorporate the prospect of a deterministic trend as well as the stochastic type of trend represented by a unit root. A number of tests can be found in Said and Dickey (1984), Kwiatkowski et. al, (1992), Perron (1988), Phillips (1987), and Phillips and Perron (1988). In this paper well-known tests proposed by Phillips and Perron (PP) and Kwiatkowski et. al. (KPSS) are applied to detect the existence of unit roots in the variables in model (7). The former test assumes the null hypothesis of a unit root while the latter test assumes the null hypothesis of no unit root. Both tests are used so that modeling directions are not inclined toward accepting one type of trend over the other. Table 1 reports the unit root test results.

Table 1: Stationarity tests

\begin{tabular}{c|c|c}
\hline Variables & PP Test & KPSS Test \\
\hline$\frac{F_{L}}{M_{L}}$ & -1.182 & $0.822 \mathrm{E}-01$ \\
\hline $\mathrm{Gr}(\mathrm{Y})$ & $-3.944^{*}$ & $0.586 \mathrm{E}-01$ \\
\hline$R_{\text {Tariff }}$ & $-4.085^{*}$ & $0.136^{*}$ \\
\hline $\mathrm{R}_{\text {fertility }}$ & -2.308 & $0.130^{*}$ \\
\hline $\mathrm{Gr}(\mathrm{L})$ & $-5.830^{*}$ & $0.989 \mathrm{E}-01$ \\
\hline $\mathrm{Gr}(\mathrm{K})$ & -2.343 & $0.145^{*}$ \\
\hline$\frac{G E N R_{\text {Hed }}}{T E N R_{\text {Hed }}}$ & -1.280 & $0.171^{*}$ \\
\hline$\frac{G_{e d}}{Y}$ & -1.742 & $0.732 \mathrm{E}-01$ \\
\hline
\end{tabular}

Notes: * - significant at the 10 percent level. The critical value for the PP test with constant and trend at the 10 percent level is -3.132 . The critical value for the KPSS test with constant and trend at the 10 percent level is .119.

Both the PP and KPSS tests confirm the presence of unit roots in $\mathrm{R}_{\text {fertility }} \mathrm{Gr}(\mathrm{K})$, and $\frac{G E N R_{\text {Hed }}}{T E N R_{\text {Hed }}}$. Both tests confirm that $\operatorname{Gr}(\mathrm{Y})$ and $\operatorname{Gr}(\mathrm{L})$ are stationary. However, the PP and KPSS test results conflict for the variables $\frac{F_{L}}{M_{L}}, R_{\text {Tariff }}$, and $\frac{G_{E D}}{Y}$. The PP test detects unit roots in $\frac{F_{L}}{M_{L}}$ and $\frac{G_{E D}}{Y}$ while the KPSS test detects no unit roots. The KPSS test indicates a unit root in $R_{\text {Tariff }}$, but the PP test does not. A common method of dealing with the presence of unit roots is to take first differences of the variables prior to estimating a model containing them. All variables that were found to be nonstationary by either of the PP or KPSS test were differenced. The differenced variables were then analyzed with the PP and KPSS tests. All differenced variables except $\frac{F_{L}}{M_{L}}$ and $R_{\text {Tariff }}$ are found to be stationary. Since $\frac{F_{L}}{M_{L}}$ and $R_{\text {Tariff }}$ are found to be stationary in levels according to the KPSS and PP tests, respectively, variables $\frac{F_{L}}{M_{L}}$ and $R_{\text {Tariff }}$ will enter the model in levels. A time trend, $\mathrm{t}$, was also included in each equation to capture the effect of a potential deterministic trend in the variables estimated in levels.

\section{Estimating the Simultaneous Equation Model}

Model (7) has been estimated by three stage least squares (3SLS). Table 2 presents the complete 3SLS

${ }^{1}$ Known as the spurious regression problem, it was popularized and studied extensively by Granger and Newbold. 
estimates of model (7). In the first equation of the SEM that explains the ratio of female to male labor force participation rate, $\frac{F_{L}}{M_{L}}$, the coefficient on $R_{\text {Tariff }}$ is negative and statistically significant. The negative coefficient indicates that a decline in the average tariff rate or an increase in the magnitude of trade liberalization increases the ratio of female to male labor force participation rate. In other words, trade liberalization contributes to greater gender equality. The variable $\operatorname{Gr}(\mathrm{Y})$ has a positive and significant coefficient indicating that economic growth lowers the gender labor force participation gap. This finding is supported by Lahoti and Swaminathan (2013) who found that in India an increase in the net state domestic product in north-eastern states increased women's economic activity.

Table 2: Estimated equations

\begin{tabular}{|c|c|c|}
\hline $\begin{array}{c}\text { Equation } 1 \\
\frac{\boldsymbol{F}_{\boldsymbol{L}}}{\boldsymbol{M}_{\boldsymbol{L}}}\end{array}$ & $\begin{array}{l}\text { Equation } 2 \\
\operatorname{Gr}(Y)\end{array}$ & $\begin{array}{l}\text { Equation } 3 \\
\frac{\boldsymbol{G E N R}_{\boldsymbol{H e d}}}{\boldsymbol{T E N R}_{\boldsymbol{H e d}}}\end{array}$ \\
\hline $\begin{array}{c}1.56 \mathrm{Gr}(\mathrm{Y}) \\
(1.65)^{*}\end{array}$ & $\begin{array}{l}0.23 \frac{F_{L}}{M_{L}} \\
(0.73)\end{array}$ & $\begin{array}{r}-0.52 \frac{F_{L}}{M_{L}} \\
(-5.11)^{* *}\end{array}$ \\
\hline $\begin{array}{c}-0.89 \mathrm{E}-01 \mathrm{R} \text { Tariff } \\
(-1.93)^{*}\end{array}$ & $\begin{array}{c}0.72 \mathrm{E}-01 \mathrm{Gr}(\mathrm{L}) \\
(1.40)\end{array}$ & $\begin{array}{c}-0.62 \mathrm{E}-01 \mathrm{R} \text { _Tariff } \\
(-3.90)^{* *}\end{array}$ \\
\hline $0.52 \mathrm{R} \_$Fertility $(0.70)$ & $\begin{array}{c}1.50 \mathrm{Gr}(\mathrm{K}) \\
(3.44)^{* *} \\
\end{array}$ & $0.19 \mathrm{E} 01 \mathrm{Gr}(\mathrm{Y})(0.31)$ \\
\hline $\begin{array}{r}-1.36 \frac{\mathrm{GENR}_{\mathrm{Hed}}}{\mathrm{TENR}_{\mathrm{Hed}}} \\
(-5.03)^{* *}\end{array}$ & $\begin{array}{c}-0.78 \mathrm{E}-01 \mathrm{R}_{\text {Tariff }} \\
\quad(-2.08)^{* *}\end{array}$ & $\begin{array}{r}-0.41 \frac{\mathrm{G}_{\mathrm{ed}}}{\mathrm{Y}} \\
(-0.73)\end{array}$ \\
\hline $\begin{array}{r}-1.35 \frac{\mathbf{G}_{\mathrm{ed}}}{\mathbf{Y}} \\
(-1.66)^{*} \\
\end{array}$ & $\begin{array}{r}1.57 \frac{\mathbf{G}_{\mathrm{ed}}}{\mathbf{Y}} \\
(1.08) \\
\end{array}$ & $\begin{array}{c}-0.33 \mathrm{t} \\
(-6.62)^{* *}\end{array}$ \\
\hline $\begin{array}{c}-0.57 \mathrm{t} \\
(-4.54)^{* *} \\
\end{array}$ & $\begin{array}{l}0.71 \mathrm{E}-02 \mathrm{t} \\
(0.52 \mathrm{E}-01)\end{array}$ & $\begin{array}{r}27.53 \\
(6.09)^{* *} \\
\end{array}$ \\
\hline $\begin{array}{c}51.77 \\
(10.33)^{* *} \\
\end{array}$ & $\begin{array}{l}-1.86 \\
(-0.13) \\
\end{array}$ & \\
\hline
\end{tabular}

Notes: t-ratios are in parentheses; E indicates scientific notation;

** -significant at the 5 percent level;

* -significant at the 10 percent level.

The coefficient on $\frac{G E N R_{\text {Hed }}}{T E N R_{\text {Hed }}}$ is negative and statistically significant indicating that an increase in the percentage of girls' enrollment in higher education results in a decline in the ratio of female to male labor force participation rate. According to the ILO (2013) report India has experienced a decrease in the female labor force participation rate over time. One of the possible reasons for this trend as stated in the ILO's 2013 report is an increase in girls' enrollment in higher education. Note that during 1990-2009 the percentage of girls' enrollment in higher education (Figure 6) increased for almost all years. Therefore, the negative and significant coefficient estimate of the variable $\frac{G E N R_{H e d}}{T E N R_{H e d}}$ provides a valid explanation for the observed decline in the ratio of female to male labor force participation rate or the increase in the gender labor force participation gap over the study period of this paper. The coefficient estimate of the variable, $\frac{G_{E D}}{Y}$, is also negative and significant implying as the share of government expenditure in GDP rises the ratio of female to male labor force participation rate falls which supports the negative and significant effect of girls' enrollment in higher education on gender equality. 
In the economic growth equation, the second equation of the SEM, the coefficient on $\operatorname{Gr}(\mathrm{K})$ is positive and significant while the coefficient on $R_{\text {Tariff }}$ is negative and significant. The negative coefficient on the average tariff rate implies that trade liberalization enhances economic growth. Since the adoption of outward oriented policies in 1991, India's economy grew at a very impressive rate. As noted earlier, a number of previous studies have found that international trade enhances economic growth. The coefficient on $\frac{F_{L}}{M_{L}}$ is not statistically significant. The insignificant coefficient on $\frac{F_{L}}{M_{L}}$ implies that there does not exist any bi-directional relationship between $\frac{F_{L}}{M_{L}}$ and $\operatorname{Gr}(\mathrm{Y})$. However, $\operatorname{Gr}(\mathrm{Y})$ depends on $R_{\text {Tariff }}$ and the coefficient on $R_{\text {Tariff }}$ is significant. Therefore, the first equation of the SEM may contain the problem of contemporaneous correlation since $\operatorname{Gr}(\mathrm{Y})$ may co-vary with the error term in the first equation, $\varepsilon_{1}$. Therefore, it is important to leave this equation in the model to address the likely problem of contemporaneous correlation in the first equation.

In the third equation, which explains the percentage of girls' enrollment in higher education, $\frac{G E N R_{\text {Hed }}}{T E N R_{\text {Hed }}}$, the variable $\frac{F_{L}}{M_{L}}$ has a negative and significant coefficient implying that a decline in the ratio of female to male labor force participation rate will increase the percentage of girls' enrollment in higher education. This captures the reverse relationship between $\frac{F_{L}}{M_{L}}$ and $\frac{G E N R_{\text {Hed }}}{T E N R_{\text {Hed }}}$; the use of a simultaneous equation model in this paper is therefore justified. The coefficient on $R_{\text {Tariff }}$ \#s negative and significant. The negative coefficient shows that an increase in the magnitude of trade liberalization raises girls' enrollment in higher education which in turn implies that trade liberalization increases girls' access to higher education.

\section{$7 \quad$ Summary and Conclusions}

This paper has examined the relationship between globalization and gender inequality in the labor market. In particular, using time-series data for the period 1990-2009 this study has explored how India's 1991 dramatic trade liberalization has impacted the gender labor force participation gap. The results show that a reduction in the weighted average tariff rate leads to an increase in the ratio of female to male labor force participation rate. In other words, trade liberalization and gender equality in the labor market are positively related. The findings also indicate that economic growth lowers gender inequality in the labor market. Additionally, this paper suggests that an increase in the percentage of girls' enrollment in higher education decreases the ratio of female to male labor force participation rate. There also exists a negative relationship between the share of government expenditure on education in GDP and the ratio of female to male labor force participation rate or gender equality in the labor market. These findings indicate that in India greater access to higher education is one of the likely causes for declining female labor market participation rate over time. Notably, these effects are likely to be stronger than the positive effects of trade liberalization and economic growth on gender equality in the labor market. Note that the sample of this study is restricted to 15-24 age groups and these age groups are likely to opt out of the labor force due to greater access to education.

Additionally, this paper finds that the relationship between the ratio of female to male labor force participation rate and the percentage of girls' enrollment in the higher education is bi-directional. The use of a simultaneous equation model is therefore justified in this paper. The findings of this paper from estimating the simultaneous equation model also reveal other interesting results. Notably, tariff reductions increase the percentage of girls' enrollment in higher education. In other words, trade liberalization leads to greater access to education for women.

Furthermore, this paper shows that trade liberalization enhances economic growth. As noted earlier, a large number of studies find a positive association between economic globalization and growth. Economic growth in this paper is also found to lower gender inequality in the labor market. Therefore, 
trade liberalization not only directly lowers the gender labor force participation gap, it also indirectly lowers the gender labor force participation gap through economic growth.

In sum, while no single econometric method provides a definitive proof of a relationship, this paper manifests a positive and statistically significant relationship between trade liberalization and gender equality in the labor market. The findings of this paper suggest that India's trade liberalization not only has enhanced economic growth it also has lowered the gender labor force participation gap. Additionally, increased trade openness also increased women's access to education. In other words, India's decision to adopt trade liberalization has resulted in increased economic growth as well as greater gender equality in two dimensions - labor market and education. Hence, India should continue to adopt policies that will further increase trade openness.

One important question that is beyond the scope of this paper is how trade liberalization impacts gender inequality in three important dimensions of human development, namely, reproductive health, empowerment and economics status. Because of lack of time-series data on the Gender Inequality Index (GII) which measures gender inequality in these three dimensions of human development, this paper has failed to examine the relationship between economic globalization and overall gender inequality in reproductive health, empowerment and economic status. Hopefully, future research in this area will address this question.

\section{References}

1. Baldwin, R.E. (2004) "Openness and Growth: What's the Empirical Relationship?" in Challenges to Globalization by R.E Baldwin and L.A. Winters, Eds., Chicago, University of Chicago Press.

2. Becker, G. (1971). The Economics of Discrimination. Second Edition. Chicago; University of Chicago Press.

3. Behrman, J, and King, E. (2002). "Competition and Gender Gaps in Wages: Evidence from 16 Countries." University of Pennsylvania Working Paper. Philadelphia, PA; University of Pennsylvania.

4. Berik, G., Rodgers, Y. and Zveglich, J. (2004). "International Trade and Gender Wage Discrimination: Evidence from East Asia." Review of Development Economics 8(2): 237-54.

5. Black, S. and Brainerd, E. (2004). "Importing Equality? The Impact of Globalization on Gender Discrimination," Industrial and Labor Relations Review 57(4): 540-59.

6. Granger, C. and Newbold, P. (1974). "Spurious Regression in Econometrics," Journal of Econometrics 2: 111-120.

7. Hazarik, G., and Otero, R. (2004). "Foreign Trade and the Gender Earnings Differential in Urban Mexico." Journal of Economic Integration 19(2): 353-373.

8. Hansson, P., and Henrekson, M. (1994). "A New Framework for Testing the Effect of Government Spending on Growth and Productivity." Public Choice 81(3-4): 381-401.

9. International Monetary Fund. (1998). "India: Recent Economic Developments," Staff Country Report No. 98/120, IMF.

10.International Labour Organization. 2013. Global Employment Trends 2013: Recovering from a Second Jobs Dip. International Labour Office. Geneva: ILO 2013.

11.Juhn, C., Ujhelyi, G., and Villegas-Sanchez, C. (2013). "Trade Liberalization and Gender Inequality," American Economic Review: Papers \& Proceedings 103(3): 269-273.

12.Kwiatkowski ,D., Phillips, P.C.B., Schmidt, P. and Shin, Y. (1992). "Testing the Null Hypothesis of Stationarity against the Alternative of a Unit Root." Journal of Econometrics 54: 159-178.

13.Lahoti, R. and Swaminathan, H. (2013)."Economic Growth and Female Labor Force Participation in India." SSRN Electronic Journal.

14.Menon, N., and Rodgers, Y. v. d. M. (2009). "International Trade and the Gender Wage Gap: New Evidence from India's manufacturing sector," World Development 37(5): 965-981.

15.Oostendrop, R. (2004). "Globalization and the Gender Wage Gap." World Bank Policy Research Working Paper No. 3256 .

16.Olsen, W. and Mehta, S. (2006). "A Pluralist Account of Labor Participation in India." Global Poverty Research Group, website: http://www.gprg.org.

17.Perron, P. (1988). "Trends and Random Walks in Macroeconomic Time Series: Further Evidence from a New Approach." Journal of Economic Dynamics and Control 12: 297-332.

18.Phillips, P. C. B. (1987) "Time-series Regression with a Unit Root." Econometrica 55: 277-301. 
19.Phillips, P. C. B. and Perron, P. (1988). "Testing for a Unit Root in Time-series Regression." Biometrika 75 : 335-346.

20.Rodgers, Y. v. d. M., and Menon, N. (2008). "Trade Policy Liberalization and Gender Equality in the Labor Market: New Evidence for India."

21.Said, S. E., and Dickey, D.A. (1984). "Testing for Unit Roots in Autoregressive-Moving Average Models of Unknown Order." Biometrica 71, 599-608.

22.World Bank. 2012. World Development Report 2012: Gender Equality and Development. World Bank. OWorld Bank. https://openknowledge. worldbank.org/handle/10986/4391 License: CC By 3.0 IGO.

\section{Appendix A: Variable List and Data Sources}

\begin{tabular}{|c|c|}
\hline $\mathrm{F}_{\mathrm{L}}$ & $\begin{array}{l}\text { Female labor force participation rate } \\
\text { for ages } 15-24-\text { World Bank. }\end{array}$ \\
\hline $\mathrm{M}_{\mathrm{L}}$ & $\begin{array}{l}\text { Male labor force participation rate for } \\
\text { ages } 15-24 \text { - World Bank }\end{array}$ \\
\hline$\frac{F_{L}}{M_{L}}$ & $\begin{array}{l}\text { The ratio of female to male labor } \\
\text { force participation rate - derived }\end{array}$ \\
\hline $\mathrm{Y}$ & Real GDP - Penn World data \\
\hline $\operatorname{Gr}(Y)$ & Growth rate of real GDP - derived. \\
\hline$R_{\text {Tariff }}$ & $\begin{array}{l}\text { The weighted average tariff rate - } \\
\text { Data book for Indian Planning } \\
\text { Commission, } 22^{\text {nd }} \text { December } 2014\end{array}$ \\
\hline$R_{\text {fertility }}$ & $\begin{array}{l}\text { Adolescent fertility rate (births per } \\
1000 \text { women ages } 15-19 \text { ) }\end{array}$ \\
\hline $\mathrm{L}$ & Labor force - World Bank. \\
\hline $\mathrm{Gr}(\mathrm{L})$ & Growth rate of labor - derived. \\
\hline $\mathrm{K}$ & Capital stock - Penn World Data \\
\hline $\operatorname{Gr}(\mathrm{K})$ & Growth rate of capital stock - derived \\
\hline$\frac{G E N R_{H e d}}{T E N R_{H e d}}$ & $\begin{array}{l}\text { The percentage of girls' enrollment in } \\
\text { higher education - Selected } \\
\text { Educational Statistics, Government of } \\
\text { India (various years) }\end{array}$ \\
\hline$\frac{G_{e d}}{Y}$ & $\begin{array}{l}\text { Share of government expenditure on } \\
\text { education in GDP }\end{array}$ \\
\hline
\end{tabular}




\section{Appendix B:}

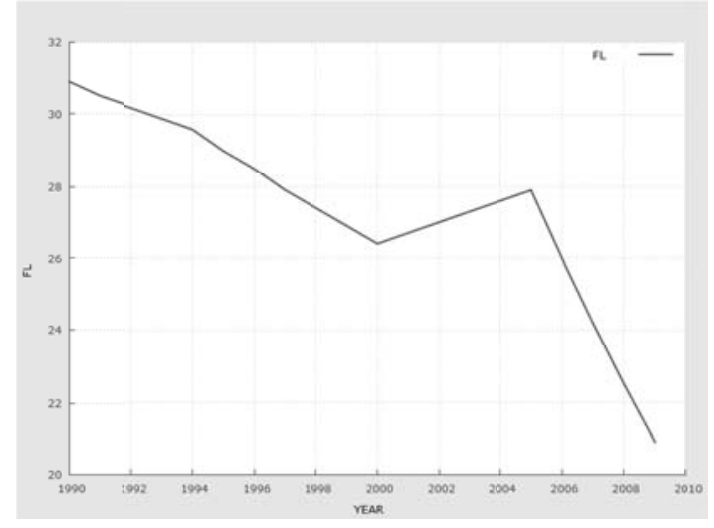

Figure 1. Female labor force participation rate for ages $15-24$

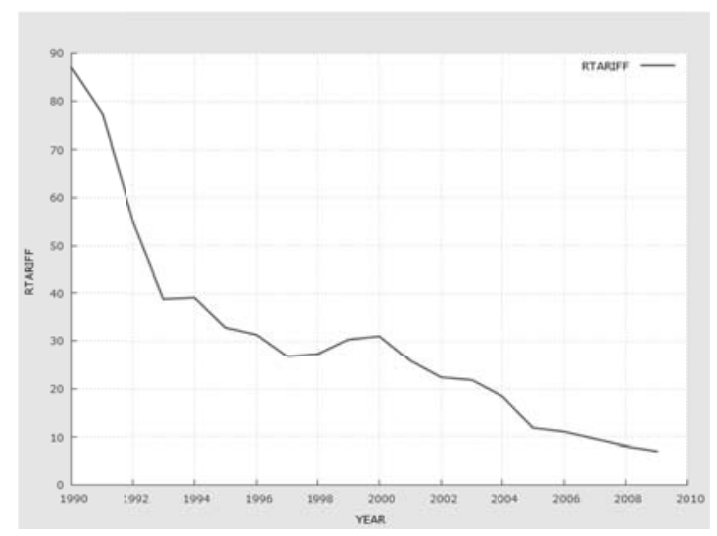

Figure 3. The weighted average tariff rate for all products

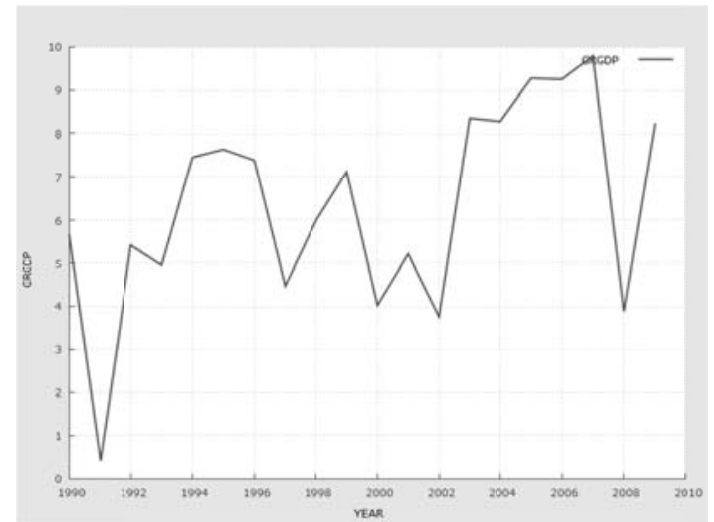

Figure 5. Economic growth rate

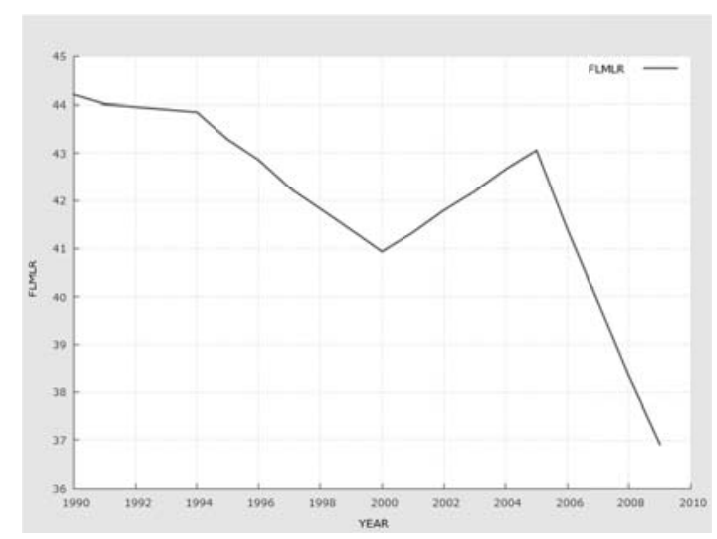

Figure 2. The ratio of female to male labor force participation rate

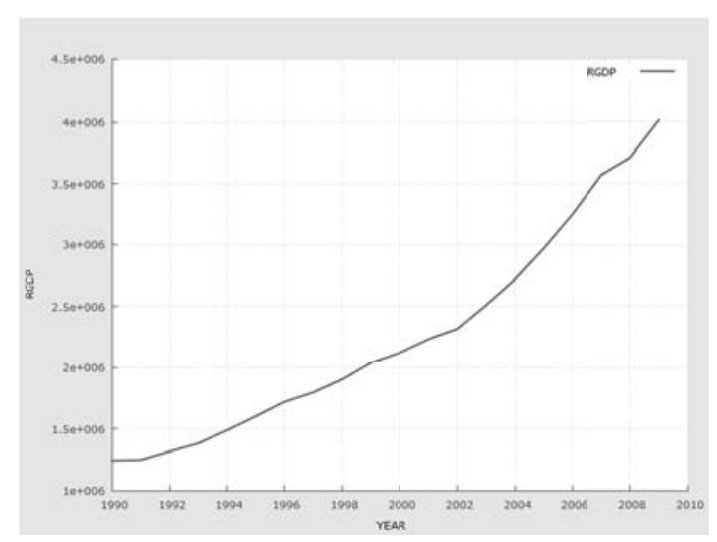

Figure 4. Real GDP

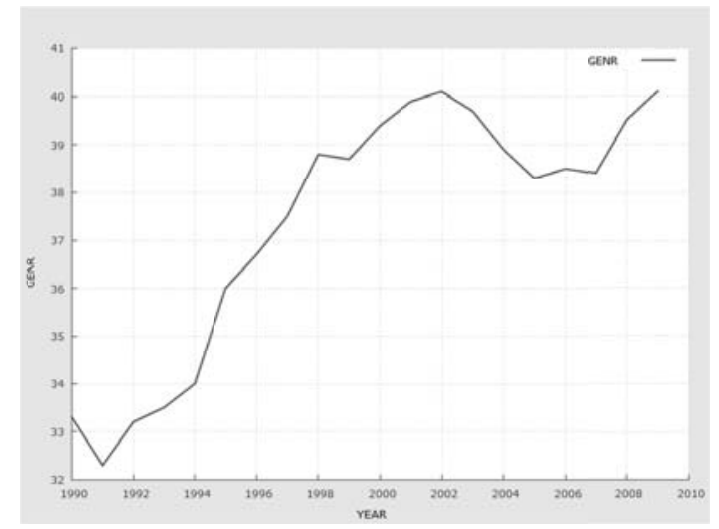

Figure 6. Percentage of girls' enrollment in higher education 